\title{
Routes to Whiteness, or How to Scrub Out the Stain: Hegemonic Masculinity and Racialization in Nineteenth-Century Puerto Rico ${ }^{1}$
}

\author{
María del Carmen Baerga \\ Professor, Department of History \\ University of Puerto Rico \\ Translated by Jane Ramirez
}

It has become almost a mantra to say that race is a social, cultural, and historical phenomenon. Nevertheless, the specific processes by which racial identities, racial hierarchies, and the various meanings of "race" itself are constructed are still, for the most part, awaiting a considered analysis by researchers. Many historical studies on race relations fail to question the concept of race, simply incorporating it as a given, just as it appears in church or census records and other official documents. It is surprising how many studies on the topic offer no definition whatsoever of the term.

Even those works that aspire to analyze the impact of sociocultural processes on the determination of racial categories are often stymied as they try to find a way around modern conceptions that link racial differences to certain somatic characteristics. If, however, race is a historical and cultural construct, it is not impossible to conceive of the existence of racial identities that are not linked to physical traits. A sense of race may manifest differently across time and space; moreover, these manifestations need not be linked inevitably with biology.

Race does not have just one single history. Thus the study of race demands a variety of approaches that take into account phenomena that are historical, complex, and heterogeneous. Such approaches, however, require that we free ourselves of many of the presuppositions on which modern thought is based

1. A slightly different version of this article appears as Chapter 4 of María del Carmen Baerga, Negociaciones de sangre: Dinámicas racializantes en el Puerto Rico decimonónico, Madrid, Editorial Iberoamericana Vervuert, 2015. 
and commit ourselves to questioning everything that seems natural, unalterable, and obvious.

One of the most surprising results of my research on perceptions of race in nineteenth-century Puerto Rico was the discovery that the racial thought in vogue at the time did not reflect the influence of contemporary racialist theories from Europe-those that gave preference to biological differences (phenotypic and genotypic) in the process of assigning racial identities. Racial discourse among Puerto Ricans in the nineteenth century more closely resembled the ideas of the seventeenth and eighteenth centuries in colonial Hispanic America. Such concepts as quality, birth, and purity of blood were used to define a person's racial condition. This process of classifying bodies involved factors such as genealogy, the legitimacy or illegitimacy of a person's birth, the appropriate marital ties, the sexual behavior of men and women, and the private and public conduct of individuals and families. As a result, this matter of adjudicating racial identities becomes remarkably porous. ${ }^{2}$

There were certain socially sanctioned ways of lightening or even erasing the stain, for individuals or entire families. Some of the many strategies were formal; others were informal. An example of the latter was to live a scandal-free life in conformity with religious and social mores, displaying good manners and prudent behavior, associating with one's social superiors, and respecting social, political, and ecclesiastical hierarchies. These tactics were often combined with formal strategies such as ecclesiastical marriage, the procreation of legitimate children, the establishment of kinship ties with social superiors, being publicly associated with men of prestige, the acquisition of a formal education, working at an occupation other than manual, and achieving some sort of distinction or concession from political or ecclesiastical authorities. A generalization about these complex processes may be made to the effect that the route to whiteness was paved with white male privilege. In the following pages we will attempt to decipher some of the intricacies of this dynamic.

\section{Scrubbing Out the Stain: The Case of Juan Eugenio Serrallés}

Juan Eugenio Serrallés was one of the most distinguished and respected citizens of Ponce, Puerto Rico, in the latter half of the nineteenth century. The founder of the prosperous Hacienda Mercedita, he is credited with introducing a number of technological improvements to local sugar production, including

2. María del Carmen Baerga, "Cuando el amor no basta: Matrimonio y racialización en el Puerto Rico del siglo XIX." Op. Cit. Revista del Centro de Investigaciones Históricas 16 (2005): 51 98, and "Cuerpos calificados/ cuerpos negociados: Sexo, ilegitimidad y racialización en el Puerto Rico decimonónico." Historia y Sociedad, 16-17 (2005-06): 20-44. 
the invention of a system for clarifying sugarcane juice that was superior to any in use internationally in the industry at the time. ${ }^{3}$

His father, Sebastián Serrallés, was a Spanish immigrant who had come to Puerto Rico from Gerona in the 1820s. A few years after his arrival, Sebastián established a sugarcane plantation and named it Hacienda Teresa after his Catalan wife, Teresa Pont y Puig. ${ }^{4}$ Although the younger Serrallés managed his father's hacienda for many years, ${ }^{5}$ in the1860s he acquired a plantation of his own. Following his father's example, he named it Hacienda Mercedita in honor of his wife Mercedes, from Ponce. ${ }^{6}$ By the end of the nineteenth century, Mercedita had become the dominant sugar refinery on the island. Juan Eugenio Serrallés built a sugar empire that included vast lands and a number of haciendas in the regions of Ponce, Juana Díaz, Utuado, and Jayuya. He also owned a brick factory and a sugar mill in San Pedro de Macorís, in the Dominican Republic, and created an industrial corporation to produce the lime used in processing sugar. His name appears in reference to a variety of other financial enterprises as well. ${ }^{7}$

When his father moved to Barcelona in the early 1860s, Juan Eugenio became the undisputed patriarch of a family business that was emblematic of the cream of Criollo society. ${ }^{8}$ The imposing Castillo Serrallés-the castle built for the family by one of Juan Eugenio's sons-still stands today in all its splendor as a symbol of the illustrious Ponce "aristocracy."

It is not surprising that the name of such a well-respected man appears in Ponce's municipal records from 1872 as a concejal regidor [city councilman]. This important position was reserved for descendants of the city's principal "pure-blooded" families, those who were supposedly free of "blots" or "blemishes" that might tarnish the luster of the genteel colonial institutions. ${ }^{9} \mathrm{He}$ was also known as a respectable family man, a man of impeccable character and morals. ${ }^{10}$ The astonishing thing about the case of Juan Eugenio Serrallés is that

3. Andrés Ramos Mattei, La hacienda azucarera, su crecimiento y crisis en Puerto Rico (siglo XIX), San Juan, CEREP, 1981. Gaceta de Puerto Rico, May 16, 1876, 1. Historic American Engineering Record, "Photographs, Written Historical and Descriptive Data, Hacienda Mercedita Foundry," HAER No. PR-8, n.d. Accessible at http://lcweb2.loc.gov/master/pnp/habshaer/pr/ pr0000/pr0094/data/pr0094data.pdf

4. Historic American Engineering Record, "Photographs ... Hacienda Mercedita."

5. Archivo Histórico Nacional, Ultramar, 361, exp. 7.

6. Interview of Julio Juan Serrallés by Humberto García, May 9, 1991. Centro de Investigaciones Históricas, Colección Material Audiovisual, Cassettes, caja 2, no. 7.

7. Historic American Engineering Record, "Photographs ... Hacienda Mercedita."

8. Edwin José Mattei, "La Central Mercedita y su supervivencia al 1898," in Mario Cancel (ed.), Ponce, 1898: Panoramas, Puerto Rico, Museo de Arte de Ponce, Fundación Puertorriqueña de las Humanidades, and Museo de la Historia de Ponce, 2000.

9. [Borrones or tachas. Translator.] Gaceta de Puerto Rico, August 31, 1872, 2.

10. Félix Matos Bernier, Cromos ponceños por Fray Justo, Ponce, Imprenta La Libertad, 1896, 26. 
his distinguished birth and position were not advantages that he had enjoyed from the start; they were, rather, a status that he acquired over the course of his life.

From a modern point of view, it is difficult to imagine that the prestigious Juan Eugenio Serrallés was not born with a silver spoon in his mouth. And yet his origins were actually very similar to those of so many children born in that period who did not receive their fathers' surnames when christened. His baptismal record, contained in the registry of pardos (mulattos), states that he is the natural son of Juana Colón. ${ }^{11}$ There is no explicit mention of his having been acknowledged by his father. ${ }^{12}$ The fact that this birth was recorded in the registry of pardos seems to suggest that his mother was publicly known as a mulatta. In fact, the lack of the honorific doña in referring to her is, in itself, a sign that Juana did not belong to one of the city's distinguished families. It is feasible that Juana may have been the type of parda who, having entered into a legal marriage with a man like Sebastián Serrallés, would have ascended to the position of doña and been considered blanca (white). It is interesting that this never happened. Does that mean that both Juana and her son would live out their lives in the devalued sphere of pardos?

Another possible explanation for this birth record's having been relegated to the registry of pardos may be the fact that the child was illegitimate, born of an unknown father, which would automatically place him in a state of racial ambiguity. This interpretation, however, is difficult to sustain when we take into account other elements that are present in the birth record. The godparents of children whose father was unknown were usually relatives or acquaintances from the same social stratum as the mother. This is not the case with Juan Eugenio; his godfather and godmother are listed with the honorific titles don and doña. This would appear to indicate that the child was under the indirect protection of his father, who made sure that his son had the advantage of respectable persons to supervise his upbringing and keep a watchful eye on his needs. It may be that designating godparents of his own social class was a means of providing for his son anonymously, without publicly acknowledging his paternity. Later events in the life of young Juan Serrallés seem to confirm this perception.

In 1850, the year in which Juan turned sixteen, don Sebastián Serrallés

11. Legally, natural offspring were "illegitimate children born to persons with no legal impediment to be married to each other for reasons of marital status or of consanguinity" at the time of conception or birth, provided that the father acknowledge them as his own. Joaquín Escriche, Diccionario razonado de legislación y jurisprudencia, Paris, Librería de Rosa, Bournet and Co., 1951, 775-776.

12. The birth of Juan Serrallés was registered in Gaudalupe Parish in Ponce, libro de pardos 23, folio 114. I was, unfortunately, unable to find the original document. All of the information mentioned here concerning that birth is located in the Archivo Histórico Diocesano, Archdiocese of San Juan, Justicia, Legitimación 1861-1899, J-223. 
took legal steps to acknowledge him as his natural son. Being acknowledged as Sebastián's son would have made it possible for Juan to continue his education and to be formally involved in his father's business affairs. Undoubtedly, it also helped him gain entrée to more prestigious social circles.

The crowning moment in Juan Eugenio's rising social trajectory came in 1867, when the queen of Spain granted him the gracia (concession or favor) of legitimation. ${ }^{13}$ Although his parents were never married ecclesiastically, the Ley de Gracias al Sacar of 1773, as well as its later revisions, allowed the monarch to legitimize children born out of wedlock, provided that the circumstances of the case met certain requirements. ${ }^{14}$ Unfortunately, Serrallés's legitimation file could not be found among those that were examined in the National Archive in Madrid; it is thus impossible to know on what basis Juan Eugenio Serrallés presented his case and who supported and justified his claim to legitimacy.

Although the available documentation is scanty, it is clear that Juan Serrallés received parental support and encouragement from his father. His accomplishments-even before his legitimation-were considerable. And then in the early 1860s, he founded his Hacienda Mercedita, at the same time that his father Sebastián departed for Spain, leaving his business affairs in the hands of his natural son. ${ }^{15}$ However, it was not until January 11, 1867 that his life was dramatically transformed. ${ }^{16}$ That is the date shown on the royal rescript that made him Sebastián's legitimate son. ${ }^{17}$ On August 21 of that same year, his father ceded to him 46.12 cuerdas in the Cotto barrio and 19.3 cuerdas in the Sabanetas barrio of Ponce. Sebastián had just bought the land, and Juan

13. Archivo Histórico Diocesano, Archdiocese of San Juan, Justicia, Legitimación 18611899, J-223, "Legitimación de D. Juan Serrallés en virtud de Real Rescripto de S. M la Reyna Ntra. Alz." Findlay mentions the case of Juan Serrallés as an example of a transition from black to white, but offers no explanation of exactly how this process occurs. That, precisely, is the object of the present discussion. Eileen Suárez Findlay, Imposing Decency: The Politics of Sexuality and Race in Puerto Rico. Durham, North Carolina, Duke University Press, 1999, 23.

14. According to the law passed by the Spanish Cortes (Parliament) and dated April 14, 1838 , the king was authorized to grant legitimacy " 1 ) to the child of parents, both unmarried, who do not share a prohibited [for marriage] degree of consanguinity 2) to the child born of an adulterous relationship between married persons who, at the time of birth, would have been in condition to marry each other due to the deaths of the spouses with whom they were respectively united at the time of conception." Escriche, Diccionario razonado, 795-796.

15. Ramos Mattei, La hacienda azucarera, 17.

16. Analysis of records of the Serrallés family's land purchases from 1846 to 1879 , compiled by historians Benjamín Nistal-Moret and Héctor Sánchez and documented in the Ponce notary records (protocolos notariales), reveals that these purchases tripled beginning in 1867, the year in which Juan was legitimized. From 1846 to 1866 only ten transactions are recorded, of which five took place from 1846 to 1860 and five from 1861 to 1866 . In contrast, from 1867 to 1879 a total of 29 such transactions were reported. Historic American Engineering Record, "Photographs ... Hacienda Mercedita, footnote 3.

17. Archivo Histórico Diocesano, Archdiocese of San Juan, Justicia, Legitimación 18611899, J-223, “Legitimación de D. Juan Serrallés.” 
claimed to have bought it from him. ${ }^{18}$ Four months later, on December 17, he bought Hacienda Laurel; he would later buy five more plantations, all of them contiguous to Hacienda Mercedita except for one property that he acquired in San Pedro de Macorís. ${ }^{19}$

A number of significant events-the expansion of don Juan's business ventures to the Dominican Republic, his invention that improved sugar production, and his entry into politics-occurred after his legitimation. This suggests that, although he may have had his father's backing from the start, Ponce society had not accepted him with open arms; this may well have been what motivated him to seek the royal dispensation.

Another inducement that, in all probability, impelled him to seek legitimacy was his desire to marry Mercedes Pérez. Although don Juan acquired his

18. [A cuerda is a unit of land measure roughly equivalent to an acre. Translator.] Archivo General de Puerto Rico, Fondo: Protocolos Notariales, Serie: Ponce, Pueblo: Ponce, Escribano: De León, Rafael, Fecha: 1875, caja: 1978, folios 436-441. It is possible that this transaction, which Juan describes as a sale, was actually an indirect way for his father to transfer assets to him, since legitimized children could, by law, inherit only one-fifth of the discretionary portion of their father's estate, unless the king had granted them, in the same decree (cédula de legitimación), the right to inherit on an equal footing with children born legitimately to legally married parents. See Escriche, Diccionario razonado, 797. Upon his death in 1874, don Sebastián Serrallés left the totality of his assets to his legal wife, doña Teresa Pont y Puig, to be held throughout her lifetime. She was also named administrator of the inheritances of the five younger children born to their marriage. Archivo General de Puerto Rico, Fondo: Protocolos Notariales, Serie: Ponce, Pueblo: Ponce, Escribano: De León, Rafael, Fecha: 1875, caja: 1978, folios 436-441. It is interesting to note that Sebastián had two other sons-Sebastián Marcial and Félix-who were incorrectly identified by Nistal-Moret and Sánchez as sons of Teresa. Historic American Engineering Record, "Photographs... Hacienda Mercedita." These two sons were surnamed Serralés y Colón, so it is reasonable to infer that they were full brothers of Juan Eugenio's. See Archivo General de Puerto Rico, Fondo: Protocolos Notariales, Serie: Ponce, Pueblo: Ponce, Escribano: Mayoral, Joaquín, Año: 1876, Tomo: enero-marzo, caja: 2224, folio 63 . The document stipulating the division of the inheritance (percibo de herencia), registered in the Ponce notary records for 1875, shows that don Sebastián's will divides Hacienda Teresa into eight parts, bequeathing one-eighth to Sebastián Marcial and one-eighth to Félix. The remaining six-eighths is divided equally among doña Teresa and her five younger children. Sebastián Marcial and Félix also receive a certain amount in cash. The document lists these two as sons of don Sebastián but does not specify whether they are natural or legitimized sons. This very omission suggests that the two were natural sons; they may have received the so-called quinto-the one-fifth of the assets that the law allows to be distributed according to the testator's discretion. See Novisima Recopilación de las Leyes de España (Dividida en XII Libros), libro X, título XX, ley VI, Madrid, 1805, 125126. Accessible at: bvpb.mcu.es/es/consulta/registro.cmd?id=403945.

Juan Eugenio is not mentioned in this distribution of assets other than to state that the others would have to consult with him, as manager of Hacienda Teresa, in order to receive their percentage of the plantation's profits. Archivo General de Puerto Rico, Fondo: Protocolos Notariales, Serie: Ponce, Pueblo: Ponce, Escribano: De León, Rafael, Fecha: 1875, caja: 1978, folios 432-435. The fact that Juan, and probably his brothers, were natural sons suggests that don Sebastián may have married doña Teresa after the birth of these three sons; otherwise, they would have been hijos adulterinos-sons born in adultery-which would have been a serious obstacle to Juan's legitimation, as we will see farther along.

19. Archivo General de Puerto Rico, Fondo: Protocolos Notariales, Serie: Ponce, Pueblo: Ponce, Escribano: De León, Rafael, Fecha: 1866-67, caja: 1972, folios 360-364. 
first plantation in $1861^{20}$ and named it Mercedita, the fact is that doña Mercedes Pérez did not become his lawful wife until after he had achieved his legitimation. Evidence of this can be found in the will that don Juan had prepared for him in 1876, in which he states that on the date of his marriage to doña Mercedes he already owned various rural and urban properties and had a capital of 70 thousand pesos in local currency. As mentioned above, his strategy of buying land contiguous to Hacienda Mercedita began after his legitimation in early 1867. As don Juan himself indicates in his will, his wife had a good upbringing and education; her family probably would not have consented to her marriage with a natural son. ${ }^{21}$

Once don Juan had achieved his legitimation and had contracted an ecclesiastical marriage with doña Mercedes, his business affairs escalated quickly and he and his family soon found themselves at the center of Ponce's social elite. Once the pardo child of an unknown father, don Juan Serrallés was now the patriarch of one of the town's principal families, enjoying all the privileges associated with whiteness and purity of blood.

One thing that sets the case of young Juan Eugenio Serrallés apart from other cases of legitimation ${ }^{22}$ is that his is the only one we know of in which the son of a parda is legitimized. The world of legitimation by royal rescript belonged to Spaniards and their descendants; illegitimacy was the patrimony of those of African ancestry. What elements conspired to make this case different? That can be elucidated only if we should someday gain access to the legitimation file. Nevertheless, the consequences of this legitimation are clear: Juan rose to the sphere of social distinction. One question worth asking is whether there were any consequences for his mother. A look at another case of legitimation might provide us with a clue.

\section{Hegemonic Masculinity and the Transformation of Racial Identities}

When don José Demetrio Ramos García from San Germán, Puerto Rico, presented his petition for legitimation to the Crown in 1856, the Queen's prosecutor (fiscal) raised a number of objections that, he insisted, would have to

20. Ramos Mattei, La hacienda azucarera, 17.

21. Archivo General de Puerto Rico, Fondo: Protocolos Notariales, Serie: Ponce, Pueblo: Ponce, Escribano: Mayoral, Joaquín, Año: 1876, Tomo: enero-marzo, caja: 2224, folios 60-63. In 1876, his eldest daughter was 7 years old, from which I calculate that the marriage took place between 1867 and 1869. To my disappointment, I was unable to locate the couple's marriage certificate.

22. I refer to those examined by Ann Twinam in her book and to those cases of legitimation in Puerto Rico that I consulted in the Archivo Histórico Nacional de Madrid. Ann Twinam, Public Lives, Private Secrets: Gender, Honor, Sexuality, and Illegitimacy in Colonial Spanish America, Stanford, Stanford University Press, 1999. 
be cleared up before a decision on the case could be made. Among these, he emphasized that no testimony or statement of any sort had been heard from the petitioner's mother, "who has a greater interest today than anyone else in legitimation." ${ }^{23}$ At first glance, there is no apparent reason why the mother would be the person most interested in the legitimation of her child. After all, the benefits of the process would fall to her son, whose status would change from "natural" to "legitimate." Nevertheless, a deeper analysis of the law reveals that both the acknowledgment of a natural son and his legitimation by royal rescript resulted in benefits that extended beyond the direct recipient of the favor.

According to Spanish law in force in nineteenth-century Puerto Rico, natural sons or daughters were those whose parents, at the time of conception or of birth, were in circumstances that would allow them to marry without need for an ecclesiastical dispensation. In other words, the offspring of parents who were both unmarried, and were not related within a degree of consanguinity prohibited by the Roman Catholic Church, were considered natural children. ${ }^{24}$ The precedent for this disposition dates back to Ley 11 de Toro of $1505,{ }^{25}$ which permitted a man to acknowledge a child regardless of whether he was or was not living with the child's mother or whether he had more than one known mate, as long as the aforementioned conditions were met. ${ }^{26}$ This law, which reeked of male privilege, accepted the possibility that a man could be in a sexual relationship with more than one woman at a time, with no obvious intentions of marriage. Nevertheless, if only by default, it also acknowledged the mother of the natural child as a woman who was worthy of ecclesiastical marriage, regardless of whether or not such a marriage ever took place. It is obvious that a father's acknowledgment bore a different ideological weight than a mother's acknowledgment. Being the natural child of a woman alone led to the most sordid of speculations. To start with, it implied that the father was unknown or indifferent. Such a disaffection might be the result of one or more of the following calamities: that the mother was unworthy of being associated with the father, much less of being married to him by the Church; that the child was the result of illicit and sinful relations (incest) that impeded an ecclesiastical marriage; or that the father's evil nature made him unable to acknowledge his child, whether by his own initiative or by the desire of the mother and her family to exclude him from the child's life. In contrast, paternal

23. Archivo Histórico Nacional de Madrid, Ultramar, 2050, exp. 1.

24. Escriche, Diccionario razonado, 775-776.

25. The Leyes de Toro was the product of an early effort to compile all the laws in force in Spain at the time; the project began in 1502 and ended in 1505, when the collection was disseminated. Later compilations, such as the Nueva Recopilación of 1567 and the Novísima Recopilación of 1805 incorporate, in their entirety, the 83 laws that constitute the Leyes de Toro. Rufus B. Rodríguez, The History of the Judicial System of the Philippines (Spanish Period, 1565-1898), Manila, Philippines Rex Book Store, 1999, 15-16.

26. Juan Álvarez Posadilla, Comentarios a Las Leyes de Toro según su espíritu y el de la legislación de España, Madrid, Imprenta de Don Antonio Martínez, 1826, 110-111. 
acknowledgment involved not only the assumption of some level of responsibility for the child but also the public acceptance of the father's association with the child's mother. ${ }^{27}$ This was of particular importance if the father had a degree of social prestige.

For example, in 1892, don Luis Vergne y Marqueti, 55 years of age and resident of the town of Patillas, went before the ecclesiastical authorities to acknowledge as his natural daughters two girls, born in 1870 and 1874 respectively, the fruit of his "illicit dealings" with Florencia Meléndez y Torres. ${ }^{28} \mathrm{Al}-$ though both parents were still alive and unmarried, don Luis testified that he could not enter into marriage "with such a woman" because of the inequality of circumstances between them and the "great opposition" of his nearest relatives. He argued that he had always provided for the support and education of his daughters, now 18 and 22 years of age, and that he desired that they might one day aspire to a better marriage. That is, he considered that the paternal acknowledgment of a "don" would win for his daughters a level of social distinction. Though they would still be illegitimate, they would climb one rung higher and rise above the mass of sons and daughters of unknown parentage. Even though don Luis was involved in a relationship that clearly would not culminate in marriage, thus transgressing existing social and religious norms, the law gave him the right to allow his daughters to benefit from his recognition of them. Such an acknowledgment would also result in benefits for the mother: being publicly linked to don Luis reflected well on her.

This reverberation was not without its contradictions. For example, when the authorities reviewed the petition, they did not suggest that the couple marry in order to legitimize their daughters automatically, as they would surely have done if the two had been social equals. Instead, they simply applied themselves to the task of investigating the stated facts of the case-that Luis and Florencia were both unmarried and not related within any degree of consanguinity that would prohibit their marriage in the eyes of the Church. Apparently accepting the impossibility of the marriage due to strong family opposition, the ecclesiastical authorities proceeded to approve the amendment to the girls' baptismal records, once don Luis's testimony had been verified. White male privilege had absolved don Luis, in the eyes of the Church and society, of the transgression that he had obviously committed. Not only was he exempt from any penalty but also, as a corollary, he transferred to his daughters and to their mother the benefits of public association with himself.

27. In the course of my research, I have not come across the case of any natural child of a known father and an unknown mother. Twinam, however, mentions that on some occasions a father, in complicity with the families and the priest, would christen a child without mentioning the mother's name, in order to protect her reputation. They would simply say that the son or daughter was the child of "a Spanish woman." Twinam, Public Lives, 67, 71.

28. Archivo Histórico Diocesano, Archdiocese of de San Juan, Justicia, Legitimación 1861$1899, \mathrm{~J}-223$. 
It is interesting that in the daughters' baptismal records, the mother's name appears without the honorific "doña." In don Luis's petition, however, he refers to her as "doña" and also calls her "señora," thus conferring upon her the honor of special discursive treatment. It is as though his privileged position-as a respectable "don"-gave him the authority to hand out social dispensations not only to his daughters but also to their mother. Here is the contradiction: the white male privilege that don Luis possessed absolved him of the moral obligation to marry Florencia while at the same time, by means of the seal of approval placed on the girls and their mother by his acknowledgment of paternity, it elevated their social status through their public association with a "don." Now, if the mere acknowledgment of a natural son or daughter was sufficient to secure certain social indulgences for the mother, then the legitimation of her child by royal rescript had the power to raise her to even greater social heights, similar to the position of a legal wife.

The Crown's authority to legitimize a child born out of wedlock was disputed by no one. The practice dated back to Roman laws and persisted until at least the late nineteenth century. ${ }^{29}$ The question that did provoke debate was, "What kinds of illegitimate children are worthy of promotion to the rank of the legitimate?" Until approximately 1800, the law recognized the sovereign's authority to legitimize any sort of illegitimate child. In 1838, however, the Cortes empowered the king to make determinations in cases of legitimation of children born outside of marriage only as defined in the Novísima Recopilación de las Leyes de España, which included the definition from Ley 11 de Toro, discussed above. ${ }^{30}$ Jurists in favor of limiting legitimation exclusively to natural sons and daughters argued that legitimation was:

an image of marriage and that it [could] not, therefore, take place in those cases in which the father and the mother were unqualified to be married to each other at the time of the children's conception. ${ }^{31}$

In other words, in effect, legitimation not only blotted out the stain on the child's birth but also automatically conferred upon the woman the status of a legitimate mother, a reflection of the status of a legal wife who procreates legitimate children.

29. Escriche, Diccionario razonado, 795-796. In 1880, don José Pons y Bernard, from the city of San Juan, obtained legitimation by royal rescript for his children, Catalina and José. However, he adduced his inability to pay for the decree, and it did not go into effect. Thirteen years later, in 1893, don José paid the fee for the legitimation of one child; one year later, in 1894, he paid for the second of his offspring. It is noteworthy that after thirteen years and at the dawning of the twentieth century, this father persisted in seeking the legitimation of his children. Archivo Histórico Nacional de Madrid, Ultramar 2083, Exp. 24.

30. Escriche, Diccionario razonado, 795.

31. Ibid. 
These complexities did not go unnoticed by those entangled in the social dynamics of the time, as evidenced by the petition for legitimation of a daughter submitted by don Augusto Seguí y García in 1863. ${ }^{32}$ This document reveals that don Augusto arrived in Puerto Rico from Spain in 1855 as aide-de-camp to the Captain General and began to frequent the home of one of the preeminent families of the city, that of Colonel Sevilla. After a time, he formed a relationship with the Colonel's eldest daughter, and in 1857 she bore him a daughter named María de la Gloria. The two were unable to marry, because don Augusto had been married since 1846 to doña Celeste Marty, who was in Spain while all of this was taking place. Years later, his wife arrived in Puerto Rico, and since she was "indulgent" of his "weakness," they lived together from that moment onward in "complete conjugal peace." Nevertheless, he averred that his "conscience" and "kindness" would not find peace until he had repaired the damage caused by his "incontinence." Thus, he implored "the favor (gracia) of legitimation for that child, with the sole object of regarding her as the legitimate daughter of Doña Carmen de Sevilla and of the petitioner for social purposes." That is, the legitimation would have the same social effect as if he had entered into a legal marriage with the mother of his daughter born in adultery. In this manner, not only would the child be granted the social position that should be hers as the daughter of a respectable family but also the mother's honor, and that of her family, would be restored, insofar as possible. Don Augusto expresses this when he states that "the entire family desires it in order to repair, as much as can be done, the shame that they are enduring." Obviously, don Augusto could not marry the mother of his daughter, but the child's legitimation would give her advantages similar to those she would have had if they had actually married. Unfortunately for don Augusto, his daughter, her mother, and the rest of the family, the 1838 law provided for legitimation only of offspring conceived as natural sons or daughters. For this reason, the Crown denied the petition, since the child in the case had been born in adultery. ${ }^{33}$

32. Archivo Histórico Nacional de Madrid, Ultramar 2059, Exp. 17. "El Sr. Seguí pide la legitimación de su hija Gloria (1863-64).”

33. Interestingly, don Augusto did not invoke the 1838 law in his petition, but rather the real cédula of 1801, which included fees for the legitimation of children of adultery with fathers who were married and mothers who were single. He argued that the law of 1838 had not been extended to the overseas territories, so the law in force was the aforementioned royal decree. After much debate, Madrid decided that the law in force was that of 1838 , for which cause the petition was denied. According to the Sala de Indias, "the object of the law of April 14, 1838, according to which only natural children may be legitimized, was to put a stop to the most notorious abuse and, as this has been greater in the overseas provinces, the Sala believes that this law was created primarily for them, since in general terms there are no grounds or reasons for limiting its strength and vigor to the Peninsula, but rather there are very powerful reasons for doing exactly the opposite." Ibid. A similar case is that of Marciala Saleces from Bayamón, who requested the legitimation of her two children, fathered by her brother-in-law. The father, don Martín Goenaga, died before they received the ecclesiastical dispensation that would have permitted them to marry. Here again the argument was made that the law of 1838 had not been made applicable 
Such was not the case of don Juan Serrallés, whose mother, plain Juana Colón, became doña Juana, legitimate mother of a son of don Sebastián Serrallés in 1867. It is difficult to determine how long doña Juana enjoyed her brandnew honorability. In 1876, when her son Juan was preparing his will, both his father and his mother had died. Even so, the manner in which the family is described in the document is profoundly revealing. In addition to offering an extensive declaration of his Catholic faith, thus anchoring them discursively in Spanishness and whiteness, don Juan Serrallés is validated as the legitimate son of don Juan Serrallés and doña Juana Colón. ${ }^{34}$ Undoubtedly, as indicated by the jurists of that era, the legitimation of don Juan created a family in the image and likeness of one instituted by means of canonical marriage, which was, almost by definition, respectable, religious, Spanish, and therefore white. Thus don Juan, as the legitimate son of a don and a doña, radiated honorability, which was, in turn, reflected in his own children, who appear in their baptismal certificates as legitimate sons and daughters of don Juan Serrallés and doña Mercedes Pérez and as grandchildren of don Sebastián Serrallés and doña Juana Colón. ${ }^{35}$

Juan did not travel alone on his journey from the pardo child of an unknown father to the respectable man who was the legitimate son of a Spanish don. The privileges of being white and Spanish that his father possessed so naturally overflowed onto Juan, and also onto Juana. It is, therefore, appropriate to conclude that at the core of the complex process of constructing racial identities in nineteenth-century Puerto Rican society were the advantages of white masculinity, just as it was manifested in this specific context. The special grace granted to white males delicately defined not only relationships between individuals but also the very laws of the state and the Church and the way that both were interpreted. Even though plain Juan Colón was the product of a sinful relationship between a parda and a Spanish immigrant, the special grace given to dominant masculinity relieved the father of facing the consequences of his infraction and poured out on the son the legitimacy and honor necessary for his transformation into don Juan Serrallés, Catholic, Spaniard, and of course, son of white parents.

overseas, but the argument was rejected and the legitimation was denied. Archivo Histórico Nacional de Madrid, Ultramar 2043, exp. 8. "Caso de Marciala Saleces, pide la legitimación de los hijos tenidos con su cuñado (1845-52)."

34. Archivo General de Puerto Rico, Protocolos Notariales, Serie: Ponce, Pueblo: Ponce, Escribano: Mayoral, Joaquín, Año: 1876, Tomo: enero-marzo, caja: 2224, folio 60.

35. See, for example, the certificate of baptism of Jorge Juan Serrallés Pérez, born in Ponce in 1886. Centro de Investigaciones Históricas, Archivos Parroquiales Diócesis de Ponce, PonceBautismos: 1880-1887. 


\section{Avatars of Whiteness: The Adaptable Body of Ramón Emeterio Betances}

The routes to whiteness, although considerably smoothed by the attributes of white masculinity, were not completely lacking in bumps and potholes. A case in point is that of don Felipe Betances-father of the renowned Puerto Rican patriot Ramón Emeterio Betances-and the family he created with his lawfully wedded wife, María del Carmen Alacán. Felipe Betances and his parents immigrated to Puerto Rico from Hispaniola in the early nineteenth century. Like many other families, they were fleeing from the political instability that reigned on that island. These immigrant families brought with them economic power and social prestige; when they settled on the western coast of Puerto Rico, they breathed new life into the region. They became involved primarily in planting sugarcane and establishing businesses. In addition, they had intellectual interests, manifested in their concern for the education of their children, in the richness of their personal libraries, and in the organization of literary or artistic gatherings (tertulias) and other cultural events in their homes. ${ }^{36} \mathrm{In}$ other words, this was a migration of families who possessed all the markers of Spanishness and whiteness.

The Betances family, who settled in the southwestern town of Cabo Rojo, was well known as part of this migratory wave. They quickly fit in with the social, economic, and cultural life of the region. Proof of this can be seen in the 1812 marriage of don Felipe to doña María del Carmen Alacán, a young woman from one of Cabo Rojoss principal families. Their home soon became one of the most prominent centers for cultural gatherings in western Puerto Rico; the intellectual elite of the region met there to discuss politics, science, and philosophy. Don Felipe Betances was a leading Freemason, and his library was one of the largest in the area. ${ }^{37}$

A challenge arose in 1840 to disturb the comfort of the Betances-Alacán family's social position. Their eldest daughter, doña Ana, was engaged to marry a young Catalan man named José Tió. Ana’s brother, Ramón Emeterio Betances, related the details of the incident in a letter to his younger sister, Demetria, in 1879 .

As for the baptismal certificate, I thought you knew all about what happened back then. When it became known that doña Ana was marrying don Pepe, since there were a lot of envious parents [padres] (envious of what?

36. Eduardo Rodríguez Vázquez, "Un médico distinguido en la historia de Puerto Rico," in Félix Ojeda Reyes and Paul Estrade, Ramón Emeterio Betances. Obras completas, vol. I, San Juan, Ediciones Puerto, 2008, 26-29.

37. Emma Rivera-Rábago, Amor prohibido: La mujer y la patria en Ramón Emeterio Betances, Ph.D. Dissertation, University of Massachusetts Amherst, May 1998, 13. 
Ye gods!), they threw in the family's face our African blood-which no Betances with any common sense has ever denied. However, then it seems that it was necessary to deny it or, in order to be in line with Spanish law, we would have to provide information about the whiteness of our blood and prove, before the eyes of the world, that we dark-skinned people [gente prieta] were as white as any Pelayo or even as any Irishman, if necessary, and it was finally proved according to the law, which turns midnight into noon. ${ }^{38}$

This narration by Betances is his answer to questions that his sister had asked him in a previous letter. In that letter, she relates an experience she had in Barcelona with an unnamed lady who refused to be seen in public with her. The woman in question gave her some disturbing news about her background. This led Demetria to suppose that she was not actually the daughter of whom she believed to be her mother, doña María del Carmen Alacán. It is impossible to know exactly how Demetria arrived at this conclusion, but we can logically deduce that, in view of the important social position of the Betances-Alacán family in Cabo Rojo, the only explanation for her supposed origin would be that she was the fruit of an illicit relationship of her father's.

Her older brother tries to reassure her by disclosing that years earlier, when the family had requested copies of their baptismal certificates on the occasion of the eldest daughter's marriage, they had discovered that Ana-and all the other children of the Betances-Alacán family_had been registered as "Negros and bastards." ${ }^{39}$ Before Ana's marriage could take place, their father, don Felipe, was obliged to take the matter to court and initiate a legal process to establish his whiteness and the purity of his blood. Although his father achieved his purpose, Ramón Emeterio declared to Demetria, "Let it be understood, then, that we are blackish [prietuzcos], and we do not deny it; but as Luis Betances would say: more honorable!" 40

This episode has been reviewed by many scholars interested in Ramón Emeterio Betances as an unequivocal example of the racial identity that he claimed. Perhaps the best representative of this posture is the historian Ada Suárez Díaz, one of the principal students of his life and work, whose judgment is often reiterated to this day with few alterations. She states in her book El doctor Ramón Emeterio Betances y la abolición de la esclavitud (Dr. Ramón Emeterio Betances and the Abolition of Slavery):

38. “Carta núm. 67, A su hermana Demetria Betances Alacán,” in Félix Ojeda Reyes and Paul Estrade, Obras completas, vol. II. San Juan, Ediciones Puerto, 2008, 164-167.

39. Ibid., 166.

40. Ibid. Italics in original. 
Betances is probably the first mixed-blood Puerto Rican with a clear consciousness of what he is in racial terms; the first to accept his condition as a mulatto, without suffering psychological distress because of some percentage of [African] blood in his veins; he is, without doubt, the first to be conscious of his negritude. To him, his racial reality is in the same category as the whiteness of whites. ${ }^{41}$

To Professor Suárez, the fact that Betances acknowledged having African "blood in his veins" defines him indubitably as a mulatto, as if this were an incontestable fact of nature. ${ }^{42}$ Moreover, the distinguished doctor's admission of his "negritude" is interpreted as an unprecedented expression of a clear consciousness of what he "was," racially speaking. In other words, the racial condition of the Betances family was manifest, and if they denied it, it was the fault of the racist society that discriminated against them.

How irrational [are] divisions by colors, those that force a man of the sensibility of don Felipe Betances to humble himself before the entire town, recruiting witnesses who will swear to what both they and the authorities know to be false. But that is one of the contradictions of the system-being is not as important as seeming to be. ${ }^{43}$

The modern viewpoint on race displayed in Professor Suárez's analysis is not very far from that shown by Betances when he writes to his sister. After all, he alleges that what the Spanish law did was to obscure a truth that should be clear to everyone: that the Betanceses were still "gente prieta" regardless of whether they had been forced to deny it. To the illustrious doctor, the reason his sister was snubbed by the aforementioned lady was as clear as day:

You, with your knowledge of the world, know about the concern over color in certain circles; and that, I feel, was sufficient-since you and I are darker than the others-for that person to move away from you in particular, who were closer to her, and to deny you in the midst of the people, whose favorite delusion is being blue. ${ }^{44}$

41. Ada Suárez Díaz, El doctor Ramón Emeterio Betances y la abolición de la esclavitud. San Juan, Instituto de Cultura Puertorriqueña, 1980, 9. Italics in original.

42. Mestizaje is a historical phenomenon that is conceived differently in different contexts. The idea of a racial mixture as a product of biological reproduction is intimately linked to modern racial thought and cannot be generalized without running the risk of naturalizing the concept of race. The position held by Suárez Díaz is a clear example of this latter concern.

43. Suárez Díaz, El doctor... Betances, 8.

44. "Carta núm. 67, A su hermana Demetria Betances Alacán," in Ojeda Reyes and Estrade, Obras completas, vol. II, 164-165. 
The emphasis that Betances gives to modern racial ideas based on skin color has blinded many present-day scholars to other elements in this episode that point to racial dynamics much more complex and varied than those anchored in skin color alone.

To begin with, if it was so obvious that the Betances family were mulattos, how can we explain the fact that Demetria did not know it? Curiously, contemporary historiography exalts to the skies the consciousness of negritude that Betances displayed but fails to notice that his younger sister knew nothing about it; this suggests (among other things) that Betances's identification with negritude was not in the public domain. If it were otherwise, how do we explain that Ramón Emeterio conceived of the family racially in one way and his sister in another?

Interestingly, all references to the racial identity of Ramón Emeterio Betances emanate from a single source: the work that his friend and biographer Luis Bonafoux published in 1901in Barcelona. ${ }^{45}$ The book is a compilation of Betances's writings, accompanied by a substantial prologue in which Bonafoux includes the famous letter to Demetria and develops a train of commentary regarding his friend's racial status. This work, titled Betances, has received recognition as "a look from the outside" at the deeds of the famed abolitionist, which builds "a racial, combative, long-suffering, and humorous image" of him. ${ }^{46}$ From this perspective, it behooves us to ask to what extent the racial representation constructed by Bonafoux had any relation to the manner in which Ramón Emeterio thought of himself, or to the ideas that people in Puerto Rico had about the Betances family's race. We should question whether the characterization produced by Bonafoux might not be the product of the posthumous image that he wanted to draw of his esteemed friend-colored, naturally, by the social, political, and cultural conceptions circulating in Europe at the dawn of the twentieth century. Although it is true that Betances, who lived the greater part of his life in Europe and received most of his education on that continent, exhibited racial ideas with a modern tone in his writings, there has not yet been a thorough and systematic scrutiny of this aspect nor of the process by which he developed his racial identity. Suffice it to say that the only recorded allusion Betances makes to his negritude appears in the aforementioned letter to his sister Demetria, in which he also tells her to burn the missive that he is sending her and to refrain from making any inquiries in writing to the priest in Cabo Rojo regarding the baptismal certificates. Although Betances may have had modern ideas about race and racial equality, he evidently understood the complicated racial dynamics of nineteenth-century Puerto Rico and the consequences of possessing an inferior racial status.

45. Luis Bonafoux, Betances, Barcelona, Imprenta Modelo, 1901.

46. Félix Ojeda Reyes and Paul Estrade, Pasión por la libertad, Río Piedras, University of Puerto Rico, 2000, 120, 122. 
The involvement of Bonafoux in this matter is different. His book is a posthumous homage to a friend who devoted his entire life to the defense of certain ideals which Bonafoux respected, though he did not share them. The passion of Betances for the independence of Puerto Rico and the rest of the Antilles from the Spanish colonial yoke is symbolized by his repudiation of the institution of slavery and the struggle for the rights of members of the black race. In Bonafoux's text, both of these causes become incarnate in the mulatto body of Betances. The fact that Betances is mulatto is underlined as a way of symbolizing his alterity and his "natural" disaffection with regard to Spain. The message that Bonafoux wishes to promulgate is that Betances, despite being educated, coming from an honorable family, and being well acquainted with European culture, was not Spanish. This is precisely the explanation for his revolutionary praxis. It is no mere chance that Bonafoux chooses to begin his work on Betances with two of his personal letters instead of one of his political or medical writings, as might have been expected. (After all, Betances became famous for his actions in the fields of politics and medicine.)

In the first letter, light in tone and addressed to his relative Teresita Tió in 1878 , Betances blames his family's precarious financial situation on the defects of one or another of his ancestors. In a jocular manner, he relates that in the time of the Conquest, there lived in Hispaniola a Spanish friar surnamed Betanzos, who disdained wealth and pomp. Viewing this repudiation as a sign of arrogance, God had punished all of his lineage, including (perhaps) Teresita and himself. "There must be some trace of the humble poverty of that Spanish friar in the Betanzes or Betanzos family of today, because I don't know of any of them from whom we can expect an inheritance," he writes to his relative. Although many members of the family had obtained assets, none had succeeded in holding on to them, and therefore (he joked), everyone named Betances was like a friar.

The second letter that Bonafoux quotes at the start of his work is the one mentioned above, to his sister Demetria. Taken together, the two letters establish (among other things) that Ramón Emeterio was a Criollo. The first makes it clear that the doctor was not wealthy; his poverty, however, was not the legacy of slavery or of ancestors who worked in "low trades," but rather of the eccentricities of his Spanish forebears, those who founded the Betances family. The second marks him unmistakably as a mulatto; Betances himself admits that through his "veins" ran African "blood," probably the result of the "adventures" (andanzas) of ancestors like the Spanish friar who, as Betances tells Teresita, "took to siring children two by two." ${ }^{47}$ Thus, although many might think otherwise, Betances was not European. This leads to the question, "But what kind of mulatto was Betances?" 
According to Bonafoux, he was a "prieto" with European physiognomy:

Yes, Dr. Betances need not have declared himself prietuzco, for the simple reason that few whites have such a thin, refined physiognomy as his. ${ }^{48}$

That is, to Bonafoux, Betances was, and at the same time was not, prietuzco. The repeated use of the phrase "the courage of the skin" to express the greatness of Betances contributes to this discordance, as he allows skin color to stand for race in spite of emphasizing that his appearance is European:

Doctor Betances displayed every type of courage known to humankind, even the courage of the skin; and you may be sure that if anyone could conceal his race, that was Betances.

What surprised us the most when we saw him, as L'Amérique said, was the beauty of his facial features: one of the noblest physiognomies of a thinker and a statesman that it is possible to see. ${ }^{49}$

One wonders, then, where the clues to the "mulatto-ness" (mulatería) of Betances reside in Bonafoux's contradictory discourse. Curiously, he situates them in the same place-in the skin-but in a very peculiar manner. As Bonafoux lists the attributes of Betances's facial features, his description evokes one of the many busts of statesmen that adorn European museums, but have little to do with a Caribbean mulatto:

The profile is rather more Arab than Roman, full of energy and pride. The complexion, of a beautiful dusky color, has the appearance of basalt. An expression of pious generosity flashes in the serene pupils of his eyes. The brow, broad and square, displays the will within the intelligence. Black hair borders that brow with a band of curls, and a long silver beard falls to the chest, giving that severe countenance the aspect of a patriarchal head.

48. Bonafoux, Betances, xii. Italics in original. In a recent publication, historian José Manuel García Leduc attributes this quotation to the Madrid newspaper El Liberal. However, a careful reading of the document reveals that the words belong to Bonafoux. García Leduc failed to notice that the quotation from that newspaper that Bonafoux inserted in his text ends with the last sentence of the previous paragraph. The same thing occurs on another occasion that will be discussed farther along in this writing, in which García Leduc mistakenly attributes a comment about Betances's racial condition to Spanish journalist Juan B. Enseñat when it is actually Bonafoux who is speaking. It is important to point out these inadvertent misattributions on the part of García Leduc, since one who reads his text will get the impression that the comments about Betances's racial condition came from different sources, which is not the case. To the best of my knowledge, the only allusions of this nature are to be found in the Bonafoux text. José Manuel García Leduc, Betances heterodoxo: contextos y pensamientos, San Juan, Puerto Rico, Ediciones Puerto, 2007, 93, 95.

49. Bonafoux, Betances, xi. 
And from all of this springs something sweet and powerful-the kindness within the intelligence, the gentleness within the strength.

Yes; this is truly the head of a statesman, of a writer, of a priest of Knowledge. ${ }^{50}$

The description of his profile as "more Arab than Roman" suggests that, in spite of this particular feature, his general appearance was Roman. The juxtaposition of features that are eminently European-for example, the patriarchal head, the intelligence, and the broad, square brow-and the "appearance of basalt" of his skin clearly evoke the image of a statue in a museum. The image in our mind is not that of a descendent of Africans but rather that of some Roman patriarch, the kind that may be seen today in any number of European museums.

The ambiguity of Bonafoux's racial discourse allows him to clearly establish what his friend is not-Spanish-while supplying enough elasticity to avoid specifying what he is. The plasticity of his characterization conjoins in the adaptable body of Betances the three roots that supposedly make up the raza Americana: Spanish, African, and indigenous American.

It is true that the color of his countenance was dusky, beautifully dusky; but aquiline was his nose, which is the feature where the African character is most dominant; delicate his mouth, perfect the oval of his face. Nonetheless, instead of conducting himself like one of his compatriots who, finding himself a delegate (diputado) in Madrid, was far less concerned with his appointed duties than with smearing his face with the whiteness of Spain and who, abashed and ashamed of his appearance, was unable to finish his first and only speech before the Congress, because General Sanz confronted him and interrupted with an extremely vulgar allusion to his being a mulatto (mulatería), Dr. Betances, who looked to me much more indigenous than of the black race, had the courage of his skin, wherever he was and whatever his situation throughout his eventful life. ${ }^{51}$

In the eyes of Bonafoux, all Puerto Ricans were mulattos; the difference was whether or not they had "the courage of the skin." In contrast to the compatriot with his face "smeared" with "the whiteness of Spain," who made a fool of himself in the Spanish parliament because he was ashamed of his origin, Betanceswhom Bonafoux now describes as indigenous (indio) - never backed off an inch. Bonafoux's discourse conceived of a chameleon body that shifts with ease from white to mulatto and from mulatto to indigenous. Interestingly, allusions to Betances's adaptable physiognomy can be found in the earliest pages of the prologue. As Bonafoux continues, comments about the racial condition of Be-

50. Ibid.

51. Ibid., xii. Italics added. 
tances become scarce, with the exception of the account of an interview with Spanish journalist Juan B. Enseñat on the occasion of Betances's participation in the Revolutionary Junta in New York. ${ }^{52}$

Bonafoux, who admitted at the time that he had not had any personal dealings with Betances, converses with Enseñat about Betances's political activities. ${ }^{53}$ He remembers having seen him in Puerto Rico when he was still a young child, in the home of his uncle, don José Julián Acosta. From that time, he has been aware of Betances as a consummate independentista and a revolutionary by conviction. "A breeze from la manigua ran through the house when Dr. Betances shook his dusky head with its unusual shades," declares Bonafoux to his journalist friend. Enseñat cannot comprehend how anyone who took pride in being a friend of the Spanish could carry out an active campaign in the Parisian press in favor of Cuban independence. Bonafoux explains the revolutionary fervor of Betances in the following terms:

Dr. Betances was born in Mayagüez, a country (sic) that is friendly with Spain, as is almost the entirety of the Puerto Rican population, but he belongs to a race that was violently mistreated and humiliated while living in the islands of the Antilles. Such offenses must have led to the germination of rebellious feelings in this good man from a very respectable family. Sr. (sic) Betances is a very distinguished physician. ${ }^{54}$

In this portion of the text, Bonafoux goes even further. Instead of merely evoking Betances's condition of "prietuzco," as he did before, he now links him directly with slavery. Despite belonging to a respectable family and being a distinguished physician, Betances wore on his skin the humiliations of that abominable institution. The chameleon body of Betances has now turned into a slave. His quarrel with Spain is his repudiation of slavery, and his repudiation of slavery is anchored in his skin. This link, however, is ephemeral. In the last part of the prologue, Bonafoux recalls his last conversation with his friend before his death.

52. Ibid., lxv-lxix.

53. Bonafoux became friends with Betances when he moved to Paris in 1894, a few years before the revolutionary's death. See the prologue by Soledad Girón in Luis Bonafoux, Literatura de Bonafoux, San Juan, Instituto de Cultura Puertorriqueña and Editorial de la Universidad de Puerto Rico, 1989, 20.

54. Bonafoux, Betances, lxvii. As mentioned previously (see note 48), historian García Leduc erroneously attributes this statement to Enseñat, when it is actually Bonafoux who is speaking. 
"After all, Doctor," I said as I made my farewells, "your language is the same as that of the pure patriots like Pi i Margall. Only you speak on behalf of the indigenous, and Pi i Margall speaks as a Catalan!"55

Once again, the adaptable body of Betances is transformed, this time to embody the most select symbol of American alterity: the indigenous people. The chameleon Betances thus shifts among the three races of the "raza Americana" like a living portent of the "cosmic race," as an ever-changing "other" that incarnates the Criollo difference in opposition to the European "uniformity."

An interesting contrast to the "look from the outside" of Bonafoux is offered by Salvador Brau, contemporary of Ramón Emeterio and from the same town, who tries to explain the anti-Spanish convictions of Betances and his adhesion to the Dominican cause during the war against Spain in the 1860s.

Son of a Dominican, related to prominent Dominicans, and drawn by his genuinely democratic principles to sympathy with the truly just cause of the people, Dr. Betances's house was readily available as the meeting place for the apostles of an anti-Spanish doctrine which did not lack proselytes ... on our island. ${ }^{56}$

Brau's opinion, formed from within nineteenth-century Puerto Rican society, attributed the identification of Betances with the Dominican cause to his familial ties with prominent persons in that country and to the democratic ideas that moved him-as well as many other members of the Criollo elite-to adopt stances that were clearly anti-Spanish. That is, from Brau's point of view, the anti-Spanish stance of Betances was typical of the Criollo elite who aspired to a more democratic society.

The one who, perhaps, offers the greatest contrast to the portrait painted by Bonafoux is Betances himself. The biographer affirmed that the famed abolitionist exhibited "the courage of his skin, wherever he was and whatever his situation." There is, however, at least one occasion on which Betances could have made public his "race," but he did not do it. Bonafoux tells of the event in his prologue: ${ }^{57}$ Betances organized a banquet at a Parisian restaurant in honor of the visit to the city of the Marquess of Santa Marta, a famed Spanish republican. Men of science, intellectuals, politicians, and diplomats responded to the invitation. Among so many distinguished persons, many toasts were proposed. The first, of course, was offered by the host, Dr. Betances, who made an "extremely elegant" speech to greet all the "eminences" who were present and to

55. Ibid., lxxiii.

56. Salvador Brau, "Vigilia de los difuntos," cited in Suárez Díaz, El doctor . . Betances, 1819.

57. Bonafoux, Betances, xiv-xv. 
praise the capacity of science and republicanism to help steer humanity toward perfection. Many more speeches followed; of special interest to this discussion is the one given by the Mexican consul in Paris, Sr. Altamirano, who stated at one point:

I belong . . . to the indigenous race, an inferior race; I have, therefore, no merit in being a republican, for since the Republic is egalitarian and seeks one level for all, I could only gain by reaching the middle social level. ${ }^{58}$

Altamirano openly embraced his condition as an indigenous American (indio) to add that those republicans who were truly worthy of admiration were the men born in the higher spheres and to positions of privilege. Among these, he gives special mention to the Marquess of Santa Marta, who believed in democracy even though he was, himself, an aristocrat. Immediately afterwards, he toasted Betances, whom he described as a man who combined "American sentiments with the reflection of the European spirit." ${ }^{59}$ Curiously, neither Altamirano nor any of the other guests who made speeches mentioned Betances as being of mixed race. The qualities for which he was praised were his prestige as a man of science, his republican ideas, and his commitment to both causes.

Admittedly, Altamirano's speech provided a perfect opportunity for Betances to make a public display of that "courage of his skin" that Bonafoux talks about; he did not do so, however. We have to wonder, "Why not?" The answer is simple: in Spain and in Paris, no one had ever even conceived of Betances as a mulatto. Proof of this is the manner in which Betances is described in a news item related to the same event that was published in El País, the newspaper of the Partido Republicano Progresista (Republican Progressive Party). It refers to Betances as "Spanish, born in Puerto Rico." ${ }^{00}$ In dozens of notes in Spanish periodicals that mention Betances during the latter half of the nineteenth century, there is no evidence that anyone thought of him as a mulatto.

His political enemies in Spain called him "renegade Borinqueño,"61 "doctor with few patients," 62 "doctor ghost-maker,"63 "filibuster chief of Lares," ${ }^{4}$ "libe-

58. La República, May 4, 1890, 1. Available at the Hemeroteca Digital of the Biblioteca Nacional de España: http://hemerotecadigital.bne.es.

59. Ibid.

60. El País, May 4, 1890, 1. Available at the Hemeroteca Digital of the Biblioteca Nacional de España: http://hemerotecadigital.bne.es.

61. La Época, July 21, 1896, 1. Available at the Hemeroteca Digital of the Biblioteca Nacional de España: http://hemerotecadigital.bne.es.

62. Ibid.

63. El Globo, March 28, 1897, 3. Available at the Hemeroteca Digital of the Biblioteca Nacional de España: http://hemerotecadigital.bne.es.

64. La Época, March 6, 1873, 2. Available at the Hemeroteca Digital of the Biblioteca Nacional de España: http://hemerotecadigital.bne.es. 
ral clergyman, and probably Mason," 65 "freeloader,"66 and "ridiculous." ${ }^{\prime 67}$ They mocked his appearance as a revolutionary and his opportunism, but they never called him black or mulatto, as they did with others:

$\mathrm{He}$ is doing well in Paris playing the role of a revolutionary, and to help him look the part, he does not shave his beard, and he cuts his hair only very occasionally. He is an old-school revolutionary, so much so that not even mulattos who have gone to the United States from Puerto Rico to boast of their importance, perhaps because in the Antillean island they are nothing more than bad typesetters, no longer see Dr. Betances as an apostle but rather as a mercantilist. ${ }^{68}$

Although the item does not mention the name of the alleged mulatto, the reference is probably to Sotero Figueroa, a typographer who emigrated to New York near the end of the nineteenth century and joined the Cuban Revolutionary Party, from which he also actively advocated independence for Puerto Rico. ${ }^{69}$ Evidently, the Spanish enemies of the Puerto Rican revolutionaries had no qualms about insulting their political opponents, to the point of refusing to acknowledge the personhood of the "mulatto typesetter." In the case of Betances, they criticized him as an upstart and an anachronism, but they stopped at that. If they had had other ammunition to use against him, they most assuredly would have used it.

Interestingly, conservative newspapers like La Época, in a notice unrelated to Betances's political activities, call him a "Spanish physician."70 Other newspapers describe him variously as a "Cuban doctor, residing in Paris" or as a

65. EL Siglo Futuro, May 16, 1882, 3. Available at the Hemeroteca Digital of the Biblioteca Nacional de España: http://hemerotecadigital.bne.es.

66. La Iberia, February 25, 1897, 3. Available at the Hemeroteca Digital of the Biblioteca Nacional de España: http://hemerotecadigital.bne.es.

67. La Lectura Dominical, October 10, 1897, 6. Available at the Hemeroteca Digital of the Biblioteca Nacional de España: http://hemerotecadigital.bne.es.

68. La Iberia, February 25, 1897, 3. Another item similar to this one was published in $\mathrm{La}$ Época, February 25, 1897, 4. Available at the Hemeroteca Digital of the Biblioteca Nacional de España: http://hemerotecadigital.bne.es.

69. La Iberia, April 11, 1895, 1. The newspaper El Globo, March 28, 1897, 3, alludes to a "mulatto typographer who suffers from delusions of grandeur." It says that "in spite of all the Betanceses in Paris and all the Loteros (sic) in New York," they would not be successful in their intention of separating Puerto Rico from Spain. Despite the typographical error, it is clear that the reference is to Sotero Figueroa. For a discussion of the contributions of Sotero Figueroa and other workers to the political struggles in the late nineteenth century in Puerto Rico and New York, see Jesse Hoffnung-Garskof, "To abolish the law of castes: Merit, manhood and the problem of color in the Puerto Rican liberal movement, 1873-92," Social History, vol. 36, no. 3, 2011, 312-342.

70. La Época, December 20, 1888, 3. Available at the Hemeroteca Digital of the Biblioteca Nacional de España: http://hemerotecadigital.bne.es.

71. La Dinastía (Barcelona), January 5, 1889, 3. Available at the Hemeroteca Digital of the Biblioteca Nacional de España: http://hemerotecadigital.bne.es. 
"Dominican physician and writer,"72 but at no time do they ever make reference to any African ancestry. On the other hand, news items that emphasize the positive characterize Betances as a prestigious man of science. For example, $E l$ Americano, a newspaper published in Paris with the aim of communicating the interests of the Latin American elite to Europeans, describes him as an illustrious man, an ardent republican, from a well-known family in the Antilles, and brilliant in the exercise of his profession. ${ }^{73}$ Others mention that he was Knight of the French Legion of Honor, director of a Spanish mineral-water establishment in France, a personage in Puerto Rico who gave valuable services to France, a wise man, a successful professional, known for his important scientific works, a poet, an orator; in sum, they describe him as a distinguished man. ${ }^{74}$

El País reprinted an article that was originally published in La Nación, a newspaper in Argentina, in which Betances is mentioned as "one of the most likable faces of the American colony in Paris." ${ }^{2}$ It explains his "love of liberty and of all generous ideas" as a product of his association with Parisian youth and of his education in France. The article, after praising all of his personal and professional qualities, concludes: "Dr. Betances is a Parisian face animated by an American heart."76

In short, European newspapers published a great number of descriptions of Betances, but none of them contain allusions to African ancestry or to racial ambiguity. On the contrary, the consensus seems to be that Betances was an American of European descent. ${ }^{77}$

\section{The Racial Condition of the Betances Family: A Contextualized Reading}

Betances viewed himself as an authentic Criollo. Proof of this is that when he describes the struggle for the abolition of slavery in the Antilles, he character-

72. El Siglo Futuro, April 28, 1882, 3. Available at the Hemeroteca Digital of the Biblioteca Nacional de España: http://hemerotecadigital.bne.es.

73. El Americano (Paris), January 27, 1873, 1. Disponible en la Hemeroteca Digital de la Biblioteca Nacional de España: http://hemerotecadigital.bne.es.

74. El País, May 14, 1888, 3; La Iberia, January 6, 1889, 2; La Monarquía, January 7, 1889, 2; La Época, December 5, 1888, 2. Available at the Hemeroteca Digital of the Biblioteca Nacional de España: http://hemerotecadigital.bne.es.

75. El País, June 29, 1890, 2. Available at the Hemeroteca Digital of the Biblioteca Nacional de España: http://hemerotecadigital.bne.es.

76. Ibid.

77. In the book by Cuban author Juan F. Risquet, Rectificaciones. La cuestión político social en la isla de Cuba, Havana, Tipografía "América," 1900, there are various listings of notable men "of color," both in the Caribbean and in several places in Europe. Betances does not appear on any of them, although they include Puerto Rico and France. See specifically pp 155-165. My thanks to Dr. Jesse Hoffnung-Garskof, who alerted me to this resource. 
izes it as a confrontation between Criollos and Spaniards. It was the "most enlightened" men of the country, according to Bentances, who displayed a "vigorous aversion" to slavery ${ }^{78}$ These forward-looking men were, first of all, Criollos:

"El Boletin Mercantil, organ of the Spaniards, unconditionally," after clamoring for the guarantees regarding property that are recognized by the Constitution, adds that if any law against that property (slaves) is passed in defiance of the Constitution, the conservatives will act in defiance of the law. ... Two conservatives (regarding slavery), two peninsular men, Messrs. R. Chavarri and Díaz Romero, are touring the Island raising funds to present opposition to the law....

Permit me to mention two names that bring honor to Puerto Rico. Messrs. Cortada and Cabrera, Criollos, large landowners, have answered the emissaries from the Centro Ultramarino that "the law must be obeyed; it is past time for Puerto Rico to rise out of the abjection in which it has been submerged by slavery, and if, by some unspeakable injustice ..., the abolition law should be suspended, they will let their slaves go free, which example will be followed by all of the radical party (comprising almost all of the Criollos), and they would exhaust their fortunes, should it be necessary, to destroy that iniquity. ${ }^{79}$

But what sort of Criollos were these who, according to Betances, could be found on the front lines of this battle? He was referring to the wealthy landowners and planters (hacendados) who constituted his own circle of support and friendship. He mentions

the efforts carried out by the rich Criollo landowners of Puerto Rico who-despite their frequent attempts, frustrated by the resistance of the metropolis-petitioned the government in Madrid in 1866, and have continued to do so ever since, clamoring to monarchies and republicans alike for "the immediate abolition of slavery, even without indemnification."

To Betances, this group of Criollos constituted the crème de la crème of the Antilles.

According to the prevalent way of thinking in nineteenth-century Puerto Rico, the landowners and hacendados - that is, the group to which Betances alludes and of which he was a member-were considered pure-blooded people.

78. Ramón Emeterio Betances, "Nota del traductor," reproduced in Suárez Díaz, El doctor... Betances, 134.

79. El Antillano, "Antillas," quoted in Suárez Díaz, El doctor ... Betances, 41-42.

80. Ramón Emeterio Betances, "Nota del traductor," reproduced in Suárez Díaz, El doctor... Betances, 137. 
This does not mean that there were never any disputes over who was or was not part of this select group, but those disputes do not invalidate the unmistakable correspondence that existed between the so-called principal families of a city or town and the condition of whiteness and purity of blood.

As a member of the Criollo elite, Betances not only associated with the very finest of Puerto Rican society, but also was a full participant in the Criollo social imaginary, replete with clear-cut sex, race, and gender nuances ${ }^{81}$ In a letter to his relative Lola Rodríguez de Tió, Betances expounds on the liberal concept of the era regarding women in politics. Like many of his contemporaries, Betances conceived of the women among the elite as important resources in the political battle, as long as their participation was confined to the domestic sphere: $^{82}$

You do very well in continuing to sow, by means of propaganda, the good seed; and Patria will do very well in later continuing that rough task. The day when our women learn to impart to their husbands and to their sons the love of homeland and liberty, our salvation will have been accomplished. ${ }^{83}$

In other words, educated women like doña Lola and subsequently her daughter Patria had the duty to sow the seed in their homes, raising children and influencing their husbands toward ideas of liberty and love of country. Like many other liberals of his time, Betances understood progress and liberty in terms of gender concepts that presupposed a formally constituted family in which each spouse had certain roles to play. The responsibilities of the women of the elite class were clearly anchored in domesticity.

Interestingly, later in that same letter Betances again brings up notions of gender, sex, and race, this time to communicate his contempt for a political enemy. On this occasion he expresses his antipathy and disdain in the following terms:

Such wretches as the scandal-monger whom no one supports are still washing their faces with the filthy sandal of a Negro prostitute; that is surely the only society with whom they have rubbed elbows in Puerto Rico. ${ }^{84}$

81. Findlay, Imposing Decency; Jesse Hoffnung-Garskof, “To abolish.”

82. For discussion of the liberal imaginary in the late eighteenth century from the perspective of gender, see María de Fátima Barceló Miller, La Lucha por el sufragio femenino en Puerto Rico, 1896-1935, San Juan, Ediciones Huracán and Centro de Investigaciones Sociales, 1997.

83. Archivo de la Universidad Interamericana de Puerto Rico, Casa Museo Aurelio Tió (CMAT), [63] "Cartas a Lola," 1880. C. 001. My gratitude to Professor Mario Cancel, who told me about and made available to me a transcription of this document.

84. Ibid. 
His political enemy was so vile that Betances could not place him on the level even of a black prostitute-a trope at that time for the lowest ignominy-but rather on that of her filthy footwear. The scoundrel could have reached such depths of infamy only by close association with promiscuous black women.

For the majority of liberal men of the time, the only women who merited a degree of respect were their wives and daughters; the rest were mere trash. Betances, as a member of the Criollo elite, shared these views on race, sex, and gender, or at least he made use of them in order to communicate with those who made up his social circle. In that sense, he was a man of his times, and that is the context in which the now-familiar letter to Demetria must be analyzed.

Bonafoux, as well as those who subsequently studied Betances, interpret some comments in that missive literally-that is, according to the letter of the text and its current meaning-while ignoring others, possibly because of the difficulty of making sense of them within the literality of their analyses. I refer, for example, to what Betances himself wrote when he exclaimed that in the church records he and his sisters are listed as "Negros and bastards." The authors who discuss this portion of the text usually allude to the "blackness" of the Betances family and to the racism of which they were the object. They overlook, however, the comment about the alleged bastard status of the offspring, which is easily invalidated by a cursory examination of Betances's baptismal certificate. In that record-first inscribed in the registry of pardos and later moved to that of whites in 1840-Betances appears as the legitimate son of $\mathrm{Fe}$ lipe Betances and María del Carmen Alacán. ${ }^{85}$ Why, then, does Betances state that they were listed as bastards? Manifestly, this expression is not a statement of fact; its intelligibility emerges when it is inserted into the symbolical universe of the prevalent notions of race in nineteenth-century Puerto Rico. As we have already seen, in colonial society there was a close correspondence between illegitimacy and African descent. In a rather sensationalist vein, Betances equates being recorded in the registry of pardos with being considered Africans and bastards in his social sphere. Even so, is there any evidence to support such an assertion? Was the Betances-Alacán family considered as such? Was the Puerto Rican racial universe in the nineteenth century strictly divided into white and black, legitimate and bastard? Was this a family that was excluded from the privileges enjoyed by whites?

This is obviously not the case. The Betances-Alacán family was not consid-

85. A transcription of Betances's baptismal record appears in José A. Romeu, "Nuestros próceres, Ramón Emeterio Betances," Isla Literaria, nos. 8-9, 1970, 9. The original is located in the Parish of Cabo Rojo, Libro No. 6 Bautismos de Pardos 1826-28, dated from 22 July 1826 to 1 November 1828. The baptismal records of Betances and his sisters were transferred to the registry of whites in 1840 by order of the Gobierno Superior. The originals of these records are located in the Parish of Cabo Rojo, Libro de Bautismos no. 15 1835-42, Libro de aciento (sic) de partida de Bautismo de Calidad blancos, 1838-1842. Romeu includes a transcription of these, as well, in the article cited above. 
ered black, much less of low degree. Proof of this is seen in the marriages contracted by the daughters. Although it is true that the engagement of Ana, the eldest sister, met with some opposition, it is also true that her marriage linked the Betances family to one of the most distinguished families on the island, and that the two families maintained close ties, as evidenced by, for example, the aforementioned letter that Ramón Emeterio sent to his relative Teresita Tió. Likewise, another of the sisters, Clara de los Santos, married a Frenchman, Justino Henri, ${ }^{86}$ and there was apparently no opposition to this connection.

Ramón Emeterio himself acknowledged that he was esteemed and respected by his society. In a letter he wrote to a close friend in 1860, he confides, "I work a lot here, I make money, and everyone treats me with consideration." ${ }^{87}$ In addition, on the occasion of an election to a Junta de Información in Madrid in 1865 to discuss the famous special laws, Professor Suárez Díaz argues that Betances was the "logical candidate" for the region of western Puerto Rico, since he already was a favorite of the people. In spite of this, he decided not to participate in the election, as he was reluctant to compromise the process due to his reputation of being anti-Spain. ${ }^{88}$ That is, not only was he esteemed by the citizens of his town but also he was able to fully exercise his rights as a citizen that permitted him, among other things, to be a candidate in an election. Such rights were reserved exclusively to those who were considered pure of blood.

Finally, Professor Suárez Díaz herself admits that the burial of don Felipe Betances, Ramón Emeterio's father, "was worthy of a true hacendado." ${ }^{89}$ Confronted with the pomp of the funeral ritual, conducted by two priests, a surprised Suárez Díaz exclaims, "No one seems to remember anymore the African blood of the Dominican immigrant." ${ }^{90}$

Were the Betanceses an indisputably black family that deceitfully passed for what they were not? Or were they rather a family that had achieved a privileged racial position by following a socially approved route? Was the justification of his purity of blood that don Felipe Betances carried out in 1840 an event that forced him "to humble himself before the entire town, recruiting witnesses who w[ould] swear to what both they and the authorities $\mathrm{kn}[\mathrm{ew}]$ to be false," as Ada Suárez Díaz posits? ${ }^{91}$ Or was it rather a strategic move aimed at defending the dignity and honor of the family, put in doubt by those who sought to tarnish them? In effect, the opposition to the marriage of doña Ana

86. Rivera-Rábago, Amor prohibido, 17.

87. "Carta núm. 58," in Ojeda Reyes and Estrade, Obras completas, vol. II, 149.

88. Suárez Díaz, El doctor... Betances, 22.

89. Suárez Díaz, El Antillano, 21. For an analysis of the socioeconomic position of the Betances-Alacán family, see Francisco Moscoso, El Cabo Rojo de Betances, Cabo Rojo and San Juan, Jornada Pro Betances, Inc. and Fundación Manrique Cabrera, 2007. This author concludes that Betances was clearly part of the Puerto Rican hacendado bourgeoisie.

90. Suárez Díaz, El Antillano, 21.

91. Suárez Díaz, El doctor... Betances, 8 . 
and don José was an insult to the honor of not only the Betances family but also the Alacáns. Offenses such as this cannot be ignored without seriously diminishing the prestige of both families. True humiliation would have come upon them had they remained passive before such an insult. It is for this reason that around the same time that don Felipe took his case to court, his wife's brother, don Pedro Alacán, was doing the same for his side of the family. ${ }^{92}$

Now then, it is necessary to analyze what concrete matters don Felipe petitioned to have validated, for which purpose nineteen men known for their honesty appeared to offer testimony. These men trace the family's trajectory and establish the manner in which they acquired prestige and respectability, facts which some were attempting to denigrate. That is precisely the reason why don Felipe presented his petitions, asking witnesses to:

Say whether I have enjoyed in the town of my residence, in neighboring towns, and in that of my birth the consideration and esteem which is owing to me for my conduct in the class to which I belong.

Say whether I am the legitimate son of the lawful marriage of doña Clara Ponce de León and of Francisco Betances, she from the most distinguished families of Santo Domingo, and he a white man of the common people in the use and possession of this quality.

Answer whether it is a fact that doña Clara, my mother, was related in immediate kinship to people of the highest class, as niece of the Archbishop of Santo Domingo, don Pedro Varela, later Archbishop of Havana, mentioning others that you know or know of, with designation of the positions that they held and the honors that they received.

Declare whether it is true that my father of the aforementioned class served the King as a First Sergeant, from which he retired or separated later, as a consequence of the vicissitudes of that country, being convinced that it would be better for him to withdraw in order to work at the [illegible] company [in order] to support the numerous family that he had, than to continue despite the promotion that he might receive.

Say whether they have known my uncle by blood José Betances, my father's brother, and whether it is true that he has a daughter and a son, as well as whether this son has devoted himself to the Church, joining the order of St. Peter and taking major orders to enter the priesthood.

92. By then the father of doña María del Carmen had died, so it was up to her brother Pedro to defend the family's honor. Félix Ojeda Reyes, El desterrado de Paris: Biografía del doctor Ramón Emeterio Betances, 1827-1898, San Juan, Ediciones Puerto, 2001, 6. Archivo General de Puerto Rico, "Información de genealogía y limpieza de sangre de Don José Alacán vecino de Cabo Rojo." Fondo Judicial: Tribunal Superior de Mayagüez, Serie: Expedientes Civiles, Juzgado de San Germán, 1940, caja 39. 
Answer whether they knew doña María Yrujo and don José Ponce, my maternal grandparents, both of them members not of the class of common whites, but rather of persons of noted distinction in every way, and of the distinguished class in Santo Domingo where they were born.

Answer whether they knew José Betances and Juana Núñez, my paternal grandparents, and whether they were known and reputed in Santo Domingo as respectable white persons of the common people, therefore and for their orderly bearing deserving from everyone their consideration, regard, and esteem. ${ }^{93}$

Far from being a public conspiracy to conceal the "blackness" of the Betances family, the justification of purity of blood launched by don Felipe constituted an act of discovery of evidence. To begin with, if this were a vile trick or a ploy to hide an unequivocal truth, all of the witnesses would have endorsed all of the points on which they had come to testify. On several occasions, however, witnesses admitted that they had no knowledge of a particular point, and on others, that they knew of it only by hearsay. In addition, don Felipe could himself have alleged that both sides of his family were equally distinguished. However, he did not say anything of the sort. From the outset he established the disparity between the two branches by referring to his mother and the rest of the Ponce de León family with the honorific "don" and doña," while not showing the same deference to the Betances family. Of these he says that they are "white [persons] of the common people (del estado llano) in the use and possession of this quality." The classification of "white of the common people" was bestowed on persons whose lineage was not completely clear, whether because certain ancestors were unknown or because one or another of them had some stain or blemish. Even so, they were persons whose stain-whether proven or imaginary-had been attenuated by means of socially accepted strategies.

Undistinguished whites, or whites plain and simple-that is, of the common people-testified to their whiteness and won for themselves greater social esteem within that group by exhibiting refined conduct. In this way they confirmed that their white ancestors had a greater weight in forming their character than any nebulous forebear, and that they were worthy of their place in the category that was reputedly theirs. Therefore it is not surprising that the first point that don Felipe attempts to establish in his justification is related to his conduct; he then asks for testimony to the fact that he enjoyed, in the town where he lived and those nearby, as well as the town of his origin, "the consideration and esteem" which he deserved for his "conduct in the class to which [he] belong[ed]." In other words, if everyone honored and respected him, the reason was that he was worthy of this position because he behaved like a man

93. Archivo General de Puerto Rico, RG 186, Juez de Letras-Masones, entries 41-44m caja 142. 
of refinement. This conduct was the barometer that measured his character and testified to the predominance of whiteness in his person.

The link between a person's racial status and his or her behavior is manifest again in the way don Felipe describes his paternal grandparents, José Betances and Juana Núñez. Although according to don Felipe they were of the common people, their "orderly bearing (porte)" made them worthy of everyone's "consideration, regard, and esteem."

According to the Diccionario de la Real Academia Española in the 1803 and subsequent editions, the concept of "porte" referred to:

1) The manner of governing oneself and behaving in the conduct of one's life and actions;

2) The good, or bad, disposition of a person, and the greater or lesser decency and illumination with which he is treated;

3) Quality, nobility, and luster of the blood. ${ }^{94}$

That is, one's "porte" or bearing did not manifest only in the way that people behaved, but even more important, it revealed their inclinations and determined how they deserved to be treated by others. The concept of "porte" was also synonymous with a person's quality. In other words, a person with "porte" was one who possessed nobility or pureness of blood. Nevertheless, just as occurred with the concept of "quality" in the Spanish-American colonial context, to which detailed qualifiers were added to denote an individual's racial condition, ${ }^{95}$ the notion of "porte" was also nuanced with adjectives to connote different racial conditions. Thus the concept of adjectivized porte unveiled the true lineage (or quality) of an individual.

In the case under discussion, their porte was arreglado (orderly), an adjective that alluded to one "who maintains regulation, order, or moderation."96 In other words, the Betanceses were people who embodied the norm, who respected the social order. Taking the next logical step, we may infer that their "orderly bearing" exteriorized their lineage, which was predominantly pureblooded or white. It appears that the Dominican elite concurred with that assessment, since Francisco, one of the sons of José and Juana-and don Felipe's father-was able to marry doña Clara Ponce de León, whose family was extremely distinguished.

Don Felipe establishes the distinguished social status of his mother, doña Clara Ponce de León, in terms that are typical for the times: by means of the

94. To consult the various editions of the Diccionario de la Real Academia Española, see http://buscon.rae.es/ntlle/SrvltGUILoginNtlle.

95. This concept was defined as "nobility and luster of the blood."

96. Diccionario de la Lengua Castellana, Madrid, Impresora de la Real Academia, 1803, p. 89, 2. Accessible at http://buscon.rae.es/ntlle/SrvltGUILoginNtlle. 
positions held and the honors received by relatives of "the highest class." Doña Clara was the niece of the Archbishop of Santo Domingo, and later of Havana, don Pedro Varela, as don Felipe adduces in his justification; in addition, several of the witnesses testified that she was also the niece of the Canon Penitentiary, don Francisco González Carrasco, and of the governor of Samaná Province, don Pedro Yrujo. Others mentioned her kinship with Captain Martínez and with the notary public (escribano) of the town of San Carlos, as well as don Manuel and don Gregorio Quiñones, both doctors of law, and other notable persons.

The intention behind this unveiling of every important person related to doña Clara was to establish the fact that such a distinguished woman as she would not have allowed herself to be linked in marriage to Francisco Betances if he and his family had not occupied a solid social position in the city of Santo Domingo. As proof of this, don Felipe emphasizes that he is the "legitimate son of the lawful marriage" of his parents. From a modern perspective this phrase might appear somewhat redundant, but in 1840 it was not so. As we have demonstrated, there were forms of legitimation that did not require that the parents be married at the moment of their child's conception and birth; further, legitimation may entirely exclude the need for marriage between the parents. The "double legitimacy" of don Felipe connoted that his mother had not been forced to marry, nor had she been obliged to accept a disadvantageous marriage because of some misstep.

In fact, some of the witnesses present the marriage of Francisco to doña Clara as evidence that Francisco is white and, accordingly, so is don Felipe. For example, don Andrés López de Medrano, doctor of public health in Mayagüez whose wife, doña Francisca Flores, was related to doña Clara, declares in his statement:

[About] the don Francisco who is reputed as a white person of the common people, at least the one making this statement has never heard anything to the contrary, nor knows of any opposition to his marriage to dona Clara, and she being from one of the most distinguished families of Santo Domingo, must affirm that on his mother's side [don Felipe] is not only white but also respectable or an hidalgo. ${ }^{97}$

Using similar logic, don Fermín Peña, who had lived for many years in the city of Santo Domingo while he was a student there, states:

Let there be no doubt that the declarant [don Felipe] is the legitimate son and from the lawful marriage of doña Clara Ponce de León and don Fran-

97. Archivo General de Puerto Rico, RG 186, Juez de Letras-Masones, entries 41-44m caja 142. 
cisco Betances, the former from one of the most distinguished families of Santo Domingo, and the latter belonging to the class of whites both in the use and possession of that quality and in that he was able to be joined in marriage to doña Clara in the aforementioned city of Santo Domingo where this matter is scrupulously examined for marriages. ${ }^{98}$

As proof that the marriage of doña Clara and Francisco Betances did not detract from the social status of the very distinguished wife, some of the witnesses comment on the couple's social life. Don Leonardo Morel, a public and royal notary, testifies that

it is publicly and notoriously known that the applicant [don Felipe] receives in the town of his residence which is Cabo Rojo all the consideration owing to an honest man, and that in the City of Santo Domingo his parents also received it, being worthy of such treatment and the regard of people of the first class, for it was seen that personal guests who came to his house included certain gentlemen of the Royal Court (Real Audiencia) of that city, and others who are first in distinction."99

One of the ways in which members of the elite legitimized each other was by establishing friendships. Social gatherings in private homes and informal visits were a ritual that made public the closeness and affection that existed among individuals and families. These acts were reserved exclusively for those who considered themselves peers.

Even before Francisco married doña Clara, the children of the BetancesNúñez family rubbed elbows with the cream of the city's society. This is confirmed by don Agustín Martínez de Santelices, a lawyer of the Courts of the Kingdom of Spain, who testified that his father, who was from the City of Santo Domingo,

knew in very great detail the origin of all of the families of that country and was exceedingly scrupulous regarding his companionship with other youths of his age, and had told him that he did not object to his friendship with young Luis, the son of don José Betanzos (sic), because in addition to the integrity of his father, he knew that [Luis] belonged to a family that, although of the common people, were white without mixture. ${ }^{100}$

That is, José, like his brother Francisco, was accepted by the elite of the city of Santo Domingo, which explains how the two were able to establish their 
own families honorably. For example, Luis Betances, son of José and nephew of Francisco, was able to take Holy Orders, an option available only to those of pure blood. Francisco himself, according to the testimony of the witnesses, served the King as a First Sergeant in the "aforementioned class" of a white man of the common people. In short, the Betances family had achieved the markers of whiteness, a fact that some were trying to obfuscate.

This demonstrates that the route taken by Felipe to vindicate his family's honor was the customary one in cases of insults like the one proffered by those who opposed the marriage of their daughter. After all, the State-the power that, in the end, formally determined the quality of a person-relied on the opinions of "honest men." These were the ones who decided who entered or exited their select group. The word of respectable men was equated with the truth. Don Miguel [Valdivieso] acknowledges this when he testifies about don Felipe as follows:

I have always held him to be an individual whose lineage is clear, and this is all the more convincing because I have always heard the same from individuals of his country who are old enough to know and are incapable of lying. It should also be noted that the aforementioned petitioner has never given reason to question his good reputation. ${ }^{101}$

Did the 19 men of distinction who testified to don Felipe's lineage lie? Did they manipulate the family history when they concluded-as some of the witnesses did explicitly - that don Felipe "was white on all four sides" of the family or that he was "white without mixture"? ${ }^{102}$ Not necessarily.

It has already been argued and documented that purity of blood, or whiteness, was a condition that could be acquired, not only from one generation to the next, but also during the course of an individual's life. It is very probable, although there is no evidence beyond the remarks that Ramón Emeterio made to his sister Demetria, that the Betances family had an ancestor who was racially ambiguous - that is, one who was illegitimate, who made a disadvantageous marriage, whose public conduct was improper, who worked at a trade that was considered low, who was coarse, who was in some way linked to slavery, or who had some degree of African ancestry. Whatever the case may have been, it did not automatically follow that that person or his/her descendants would be condemned to remain perpetually in that "devalued" sphere. There were socially accepted routes to the transformation of that condition.

101. Ibid.

102. Félix Ojeda, for example, gives the following opinion regarding the file opened by don Felipe Betances: "After two months of producing a chain of false testimony in the Superior Court of Mayagüez, don Felipe Betances, one of the great hacendados of the region, succeeds in having his blood decreed pure." Ojeda, El desterrado, 16. 
Once this was achieved, a person and his/her descendants could be legitimately acknowledged as white and pure of blood. This is precisely what validates the justification of purity of blood that don Felipe carried out, and His Honor the Learned Judge (Juez Letrado), whose responsibility it was to evaluate the collected testimony, so acknowledges:

Certainly a considerable number of witnesses, all irreproachable ..., give detailed information about the ancestry and roots from which this individual has descended in relation to both lines: all of them referring to him and to his parents, and to some of his maternal and paternal grandparents, discovering their ties of kinship, the positions they held, the honors they received, the class to which they belonged, and the general regard in which they were held, [the witnesses] leave no doubt that they received the public esteem and general regard that are persuasive as to the class in which they lived and which corresponded to them, and in addition that the way they conducted themselves and their bearing did not [bring contempt upon] the sphere to which they belonged. ${ }^{103}$

The Betances family had acquired the markers of whiteness, precisely as detailed by the judge, and therefore they had won the privilege of being considered white and pure of blood. This fact does not rule out the possibility that they did, in fact, have some ancestor who was regarded as not white; however, that stain had been scrubbed out. It is also possible that there were some members of the elite who did not share this point of view; that is, they may have felt that the blemish had not been sufficiently expunged or that it was simply indelible. This explains the objections of some to the marriage between doña Ana and don José.

Who these people were and how they regarded, concretely, the stain of the Betances family is an aspect of this story that is, unfortunately, unknown. Ramón Emeterio himself offers, however, a few clues in his letter to Demetria. For example, he avers, "When it became known that doña Ana was marrying don Pepe, since there were a lot of envious parents (envious of what? Ye gods!), they threw in the family's face our African blood." ${ }^{104}$ It is difficult to specify exactly which parents (padres) are meant in this comment. It is not clear whether Ramón Emeterio refers to the parents of the groom, to parents in general in the town, or to padres, meaning priests. As has already been mentioned, the law recognized the right of the father of the bride or groom-or in his absence, the mother or other relatives-to oppose the marriage. Occasionally, parents

103. Archivo General de Puerto Rico, RG 186, Juez de Letras-Masones, entries 41-44m caja 142.

104. "Carta núm. 67, A su hermana Demetria Betances Alacán," in Ojeda Reyes and Estrade, Obras Completas, vol. II, 164-165. 
whose son or daughter wished to marry into a family whose lineage was not completely clear would oppose the union as a strategy to oblige the party in question to initiate a petition for justification which, if successful, would serve to clear away all doubts and neutralize any enemies. Nevertheless, this does not appear to apply to this case, since the parents of don José had no reason to be envious regarding their son's marriage. Such sentiments might have been more feasible among parents who belonged to the town's other principal families, who might very well have resented the fact that don José was marrying the daughter of the Betances-Alacán family and not their own. If that were the case, they would not have been allowed to present a formal opposition to the marriage, as the law made no provision for such actions. All that objectors could do in such a situation would be to start rumors, distribute anonymous posters or flyers, or hurl insults in public. This scenario, although plausible, does not appear to be supported by the smallest vestige of the known evidence.

Those whom Ramón Emeterio does point out, assigning concrete motives for desiring to bring harm upon his family, are the priests of Cabo Rojo. He relates that when his father, don Felipe, was busy with formalities-it is not clear whether he meant the ordinary proceedings for the wedding or those stemming from the objections to it-he had to go to the parochial office in the town to request baptismal certificates. It was at that moment that it was revealed that the priest had recorded their names in the parochial registries as "Negros and bastards."

During those errands it was necessary to apply to the parish priest; and this good gentleman, Father Vélez-may God forgive him-was for some unknown reason an enemy of the family. (Now I remember that my mother never, to my knowledge, went either to mass or to confession, and she died without calling for a confessor. No priest, other than Father Durán, ever visited our house. My father had no relations with any of them, and he never was a member of any brotherhood [cofradía]. He was a Mason. He attended Low Mass on Sundays, staying very far back in the Church, without ever sitting down or using the principal pews, and he held me by the hand.) The priest, then, presented the baptismal records in which all of us, Ana and the rest, were listed as Negros and bastards. ${ }^{105}$

Interestingly, in this portion of the letter to Demetria, Ramón Emeterio speaks only of the disaffection that his parents showed toward the Church. His mother did not go to mass and died without confession. His father, although he was authorized to sit in the principal pews - a fact that is never brought up by those historians who insist on the "negritude" of the Betances family-declined to 
do so; he also avoided social contact with the clergy and did not join religious associations. In this particular, the Betanceses transgressed one of that era's markers of Spanishness and whiteness; it is not surprising that the representatives of the Church in the community should be the ones to point a finger at them. The Betances-Alacán family may have achieved the position of pureblooded whites, but their actions with respect to the Church told a different story. Therefore the priests of Cabo Rojo were reluctant to acknowledge the prestige that they had acquired. Their reticence was so tenacious that even when the political authorities recognized the family's whiteness and purity of blood, the priest who recorded the marriage of doña Ana and don José in the parochial registries denied the honorific "doña" or "don" to the bride and her parents, while including it in reference to the groom and his parents. ${ }^{106}$

The passage of time did nothing to soften the attitude of the priests of Cabo Rojo toward the Betances-Alacán family. In 1879, when Demetria approached them to inquire about her baptismal record, she had no better luck than her father did nearly forty years earlier, judging from Ramón Emeterio's remarks in his letter to her.

It would be no surprise if the priest of Cabo Rojo wanted to savor the pleasure of putting you through a hard time, to prolong the vengeance of Father Vélez. Give me an exact copy of the baptismal certificate that he sent you; find out the location of the archives from which he took it, whether it was in his house and in what chamber, or in the Sacristy. What is the priest's name? Does he have a grudge against the family? What does he keep in the files? Don't ask for anything in writing. ${ }^{107}$

Evidently, there was animosity between the priests of Cabo Rojo and the family, and it had not eased with time. Although the Betances-Alacáns had prevailed - that is, they kept their position as a principal family of the towntheir opponents did not back down. Many years later, it seems that they continued to challenge the position acquired by this family. Nonetheless, although there were many bumps and potholes on the family's route to whiteness, that does not mean that they failed in their attempt or that they did not receive the benefits of having gained access to the treasure chest of honor. After all, the white identity was as slippery and unstable as other racial identities of the era.

The racial characterization of the Betances family that appears in contemporary historiography-based exclusively on a single source, the Bonafoux text-is the result of applying notions foreign to the complex dynamics of racialization that prevailed through a good part of the nineteenth century, and

106. Suárez Díaz, El doctor ... Betances, 7.

107. "Carta núm. 67, A su hermana Demetria Betances Alacán," in Félix Ojeda Reyes and Paul Estrade, Obras completas, vol. II. 
of the selective reading of Bonafoux. The idea that the racial condition of a person was predetermined by a clearly defined biological heritage was far from the thought on racial formation that was current in nineteenth-century Puerto Rico, particularly the first half of that century, when the incidents surrounding doña Ana's wedding occurred. It is true that some of the remarks made by Ramón Emeterio in 1879 regarding this incident display a modern perspective on race. After all, he lived most of his life, and received almost all of his education, in Europe. It is also true, however, that other comments of his are impossible to explain from that perspective. It is specifically the comments by Betances that are resistant to modern racial logic that contemporary historiography has ignored and excluded from its analysis. This selective reading has led some-Ada Suárez Díaz and José M. García Leduc, for example-to conclude that Betances possessed a stable and obvious racial identity. ${ }^{108}$ This argument is difficult to sustain in view of the patent exaggerations contained in the letter, the younger sister's ignorance of the incidents surrounding her elder sister's wedding nearly forty years earlier, Ramón Emeterios's warning to Demetria to destroy the latter and not to ask the priests in Cabo Rojo for any document in writing, and the fact that the male Betanceses exercised the rights of citizens. If we add to this the absence of public statements by Betances regarding his racial identity, it becomes manifest that this is a topic that demands broader research and deeper theoretical reflection.

In any case, the remarks that Betances wrote in his letter to Demetria suggest that he moved easily between two different racial conceptions. On the one hand, his discourse shows the influence of modern racial thought anchored in biology and color. On the other, he expresses ideas that are foreign to the modern view when he gives preference to such matters as illegitimacy, intra-elite conflicts, and the family's rejection of Catholicism.

In fact, due to the flexible and negotiable character of the nineteenthcentury racial system-precisely because it played a determining role in the development of social hierarchies, on the one hand, and because it was a porous regimen based on the consideration of complex criteria, on the other-it emerged as a social space that was ideal for working out contention between members of the local elite. On numerous occasions, conflicts of many different natures were signified as disputes over racial identities. This was an effective way to cast doubts upon the reputation of one's adversaries and, if they should be defeated, annihilate them socially. ${ }^{109}$

108. Others who appear to reproduce this same stance are Andrés Ramos Mattei, Carlos M. Rama, Felix Ojeda, and Manuel Maldonado Denis. See Andrés Ramos Mattei, Betances en el ciclo revolucianario antillano: 1867-1875, San Juan, Institute of Puerto Rican Culture, 1987; Carlos M. Rama, La independencia de las Antillas y Ramón Emeterio Betances, San Juan, Institute of Puerto Rican Culture, 1980; Ojeda, El desterrado; Manuel Maldonado Denis, Betances, revolucionario antillano y otros ensayos, Río Piedras, Editorial Antillana, 1978.

109. For example, the Boletín Mercantil, a conservative newspaper published in Puerto Rico 
Respectable men - heads of the principal families of a town or city-set themselves up as social doormen who obstructed or eased the entrance to, or exit from, the sphere of privilege. Ramón Emeterio Betances belonged to one of the principal families of the island and, consequently, possessed the social status and all of the privileges of a white male, a position that he never publicly denied. Although Ramón Emeterio may have expressed certain modern ideas about race, it does not follow that that mentality was necessarily in operation in the rest of the family or among the members of the elite in charge of opening or closing those social doors. The route to whiteness is often full of twists and turns and other complexities. If you look at it outside of its own context, you will never see the path clearly.

until 1918, in a news item that criticizes the independence movements of Cuba and Puerto Rico, reacts to a publication that describes as Puerto Rico's "honor" the "dark Dr. R.E. Betances." The use of "dark" (oscuro) in regard to Betances surely has racial undertones. However, I do not believe that the reference is to his skin color but rather to the lack of clarity about his lineage, since his father's family came from the Dominican Republic. In any case, the strategy of debasing the social status of one's political adversary was common in the politics of the era. "España y Santo Domingo," Boletín Mercantil de Puerto Rico, June 23, 1875, 2. 